\title{
Inter-Community Cooperation at a Regional Level: Methods of Assessing Migration and Institutional Ties
}

\author{
Sierhiei Sakhanienko ${ }^{1}$, Natalia Kolisnichenko ${ }^{2}$, Hanna Koval ${ }^{3 *},{\text { Oksana } \text { Dulina }^{4} \text {, and Temirbay Zhiemuratov }}^{5}$ \\ ${ }^{1}$ Odessa Regional Institute for Public Administration of the National Academy for Public Administration under the President of \\ Ukraine, Odessa, 65009, Ukraine \\ ${ }^{2}$ Odessa Regional Institute for Public Administration of the National Academy for Public Administration under the President of \\ Ukraine, Odessa, 65009, Ukraine \\ ${ }^{3}$ Lviv State Univerrsity of Life Safety, Lviv, Ukraine \\ ${ }^{4}$ Odessa Regional Institute for Public Administration of the National Academy for Public Administration under the President of \\ Ukraine, 65009, Ukraine \\ ${ }^{5}$ Berdakh Karakalpak state university, 230100 Karakalpak Republic, Uzbekistan
}

\begin{abstract}
The article reveals the assessing methods of inter-community cooperation at the regional level regarding its migration and institutional ties. The recommendations on the assessment of inter-municipal relations are focused on the development of appropriate strategies for cooperation between local communities. The article defines the algorithm of analysis and evaluation of inter-municipal relations. The essence and peculiarities of the relevant stages of cooperation are examined and revealed. The components of the assessment of inter-municipal relations and methods of their definition are offered. The matrix and the corresponding coefficients of inter-municipal ties are examined.
\end{abstract}

\section{Introduction}

At the current stage of public administration reform in Ukraine the local communities are required to increase the efficiency and effectiveness of local selfgovernment authorities in addressing all issues of local importance, especially of administrative and social nature, of territory development etc. This is mainly relevant for rural areas, because quality and standards of living (level of social and economic development) in urban and rural areas differ significantly. Today, most rural local communities are not able to ensure proper solution of issues related to the livelihoods of their residents. This is mainly because of the lack of local self-government own resources, especially at the level of those local communities that have not yet practice municipal consolidation within the voluntary amalgamation of local communities. However, the analysis of amalgamated local communities clearly shows that in many cases they have not become selfsufficient communities. That does not provide the expected qualitative improvement of the living conditions.

Meanwhile, one of the ways to increase the level of social and economic development of rural areas is a combination of various types of resources based on cooperation of local communities. Its legal framework was acknowledged in 2014 after the adoption of the Law of Ukraine "On Cooperation Between Local Communities" [1]. Despite the fact that local communities differ significantly in number of residents, area, structure of local economy, it is often more profitable to solve the issues of local importance together with other local communities than to implement them independently. The organization of inter-municipal cooperation in order to address the issues of local importance ensures self-sufficiency of local communities (necessary for sustainable development), creates conditions for economic and social well-being of the residents.

At the present stage, the practice of local communities cooperation in Ukraine is mostly fragmentary one. The strategic and program documents of local communities do not comprise the issues of inter-municipal cooperation, which inhibits the development of ties between them. In Ukraine 121 agreements were concluded (the data of the Ministry of Regional Development, Construction, Housing and Communal Services) according to the Register of Agreements on Cooperation between Local Communities (January 11, 2018) [2]. Most of them are aimed: i) to implement the joint projects on coordination and implementation of activities of cooperating entities; ii) to accumulate communities resources for some definite period of time. The other forms of cooperation are less popular (e.g. delegating one or more tasks to one of the subjects of cooperation with the transfer of relevant resources or the formation of joint utilities, institutions and organizations by the subjects of cooperation). Such form of cooperation as the formation of the subjects of cooperation of a joint governing body for the mutual implementation of the statutory powers is not used at all. The prevalence of local communities cooperation is also noteworthy: almost half of the agreements on cooperation are 
concluded in Poltava region, and in some regions of Ukraine they are not concluded at all.

The potential effectiveness of local communities' cooperation actualizes research and methodological relevance of inter-municipal interaction, search of new forms and models of cooperation between the municipalities in the sphere of social and economic development and in the field of management.

\section{Theoretical framework}

A rather small amount of literature is devoted to the institute of cooperation between the local communities because of its short-term introduction into the practice of municipal governance. The relevant works are aimed to provide a scope-wide theoretical analysis of cooperation between local communities [See, e.g. 3; 4; $5]$, the legal basis of inter-municipal cooperation [See, e.g. 6; 7], foreign experience [See, e.g. 8; 9], forms of cooperation [See, e.g. 10;11;12], some aspects of social and economic [See, e.g. 13; 14; 15] and managerial effectiveness of inter-municipal interaction [See, e.g. 16; 17]. In 2017, the first dissertation was defended in Ukraine [18], which comprehensively analyzed the current state and prospects for further development of cooperation between local communities as one of the priority areas of national local government reform.

But despite the emergence of a wide complex of systematic studies on cooperation between local communities, a number of disputable issues regarding this form of inter-municipal governance remains unsolved. In particular, the analysis of the needs of cooperation between specific local communities and regions is not examined. That is why there is a need in effective and tested methodology for assessing the potential and development of such cooperation.

The objective of the article is to develop the guidelines for the assessment of inter-municipal relations at the regional level aiming to work out an appropriate strategy for the cooperation of local communities under specific conditions.

\section{Discussion and results}

Inter-municipal cooperation is an organizational and legal manifestation of cooperative relations between local communities and their bodies. The communities develop their cooperation in many ways, including by [19]: advocating in policy dialogue with governments; improving mechanisms to fund their operations and increase their independence and responsiveness to community needs. The forms of inter-municipal cooperation, depending on their organizational and legal content, can be both contractual (making agreements on cooperation, joint activities), provided by the Law of Ukraine "On Cooperation between Local Communities" and associative (creation of intermunicipal associations), provided by the law of Ukraine "On Associations of Local Self-government" [20]. However, there is a variety of forms of intermunicipal cooperation between local communities and their bodies: joint consultations; joint coordination, advisory and/or consultative bodies, working groups (without legal entity status), etc.

In fact, in practice of any self-government body there are various forms of cooperation at least with the neighboring local communities. This circumstance, as well as the processes of voluntary amalgamation of local communities, involve the analysis of the factors that determine the cooperation of local communities and the monitoring of this cooperation.

A required prerequisite for the development of cooperation between local communities is the analysis of the degree of inter-municipal relations and the identification of attraction of local communities to each other.

However, there are many difficulties in conducting a qualitative analysis due to the lack of research on this issue, the weak development of municipal statistics, the lack of tested methods for assessing inter-municipal relations. As a result, it is proposed to develop the guidelines for the analysis of inter-municipal interaction and its assessment in relation to the region as a whole, sub-region (district) or a particular set of local communities. While developing the topic on inter-municipal relations of Zhmerynka raion of Vinnytsia region, an attempt was made to develop an appropriate methodology. This technique involves a certain algorithm for analysis and evaluation of intermunicipal relations:

Step 1. Provide comprehensive analysis of social and economic development of the selected area.

Step 2. Study the basic program documents of local communities.

Step 3. Identify and evaluate inter-municipal ties.

Step 4. Reveal the directions and forms of cooperation development between local communities.

At the first stage, a comprehensive analysis of the social and economic development of the selected area (as a whole area), which includes, in particular, determining the budget supply, investment component, infrastructure development, social status in local communities, as well as appropriate rankings.

The second stage involves the study of the main legal and program documents of local communities, which are examined to identify the existing interactions with other local communities and the degree of their development. This stage allows to determine whether local communities have: i) strategic guidelines for the development of inter-municipal relations; ii) the goals of these interactions, which are set out in the program documents.

At the third stage, it is proposed to identify and assess inter-municipal relations within the following aspects:

- between local communities within several neighboring raions;

- between local communities within the raion and the local community of the city of oblast importance (in the case when the city of oblast importance is the raion center);

- between local communities within one raion.

At this stage, it is necessary to identify the types of inter-municipal relations, including resource, 
migration, economic, infrastructural, social, institutional relations. At the same time, the quantification of resource, economic, infrastructural and social links is complicated by the lack of required data in State and municipal statistics. That is why the analysis of these types of ties is of expert nature. Migration and institutional ties can be quantified while using the following instruments.

Migration ties. It is recommended to use the following indicators to quantify inter-municipal migration ties:

- absolute indicators that characterize the scale and power of migration - the number of those who arrived, left or both of them (migration turnover);

- coefficients of migration ties intensity, which allow to establish the degree of ties' intensity between local communities according to the proposed scale of values;

- the coefficient of effectiveness of migration ties, which shows the amount of migration exchange between each pair of local communities.

The application of the whole set of indicators gives the most accurate assessment of migration ties, and in order to prevent possible randomness in the assessment, the calculations should be made over several years.

The number of population which arrive and leave a local community in statistical collections is given in one figure, regardless of the place of departure and arrival. Thus, the data on inter-municipal migration can be obtained only on the basis of the analysis of primary material of the territorial agency of the State Statistics Service of Ukraine and the State Migration Service of Ukraine.

The indicators can be presented in tabular form for the analysis of migration relations between local communities. Such a table is a square matrix of order $m$ ( $m$ is equal to the number of local communities of "departure" and, accordingly, the local communities of "arrival"). The peculiarity of the obtained matrix is that its elements, which are located on the main diagonal (which is passing from the upper left corner to the lower right corner) are meaningless, because the local community of "departure" coincides with the local community of "arrival". Thus, in any pair of local communities there is one direct response and one feedback.

To calculate the intensity factor, it is advisable to use the coefficient of intensity of migration ties (CIMT), proposed in the 70's by L.Rybakovsky [21]. In contrast to the general coefficients of migration intensity of the population, CIMT is used to analyze migration between local communities and characterizes the scope, results and intensity of migration exchange between administrative-territorial units. In addition, CIMT allows to compare the levels of population's mobility of different (regarding their rank and size) local communities, to identify the dynamics of migration between the territorial units which are examined. However, the complexity of calculations and the amount of necessary information did not make CIMT a popular indicator in the migration analysis (though it is absolutely adequate).
Current statistics on the migration of the population are used to calculate the intensity coefficients of the migration ties between local communities. In the proposed method one finds the proportion of all "departure" local communities in the migration of the population with each "arrival" local community separately. At the same time one calculates the proportion of each "arrival" local community in the total population of all local communities. Then the first series of values (share of local communities in migration) is divided by the second series of values (share of local communities in the population). The corresponding formula for the calculations is as follows:

$$
K_{i j}=\frac{M_{i j}}{\sum_{1=1}^{m} M_{i j}} \div \frac{S_{i}}{\sum_{l=1}^{m} s_{i}}=\frac{M_{i j} \sum_{i=1}^{m} s_{i}}{S_{i} \sum_{1=1}^{m} M_{i j}}
$$

where

$\mathbf{K}_{\mathbf{i j}}$ - intensity coefficient of migration ties between local communities;

$\mathbf{M}_{\mathbf{i j}}$ - the number of migrants who arrived from the "departure" local community $\boldsymbol{i}$ to the "arrival" local community $\mathbf{j}$;

$\mathbf{S}_{\mathbf{i}}$ - the population of the "departure" local community $i$;

m - the number of all "departure" local communities.

It is proposed to divide the obtained values of coefficients into 5 groups. The first group includes coefficients with values up to 1 ; the second group from 1 to 2; the third - from 2 to 4 ; the fourth - from 4 to 8 and the fifth from 8 and above. According to the proposed method, the ties of each group are defined as insignificant, noticeable, medium, high, higher.

After that, for the most complete assessment, the coefficient of effectiveness of migration ties (CEMT) is calculated. It shows the value of migration exchange between each pair of local communities:

$\mathrm{CEMT}=($ Number of persons who left/Number of persons who arrived) (2).

The matrix of average values of intensity coefficients of migration relations between local communities of Zhmerynka raion and neighbouring raions and cities of oblast importance in 2018 (table 1) can be calculated using the data from the State Statistics Service of Ukraine. Similarly, migration ties between individual local communities within a raion and/or a sub-region are assessed, although the territorial agencies of the State Statistics Service of Ukraine do not yet conduct statistical analysis of individual communities within raions. This necessitates the introduction of municipal statistics, which, in particular, is the objective of the Register of Local Communities, the need for which is determined by the legislation of Ukraine. 
Table 1.The matrix of average values of intensity coefficients of migration relations between local communities of Zhmerynka raion and neighbouring raions and cities of oblast importance

\begin{tabular}{|c|c|c|c|c|c|c|c|c|c|}
\hline \multirow[t]{2}{*}{ Departure } & \multicolumn{9}{|c|}{ Arrival } \\
\hline & 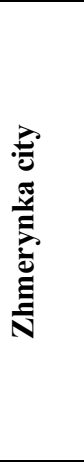 & & 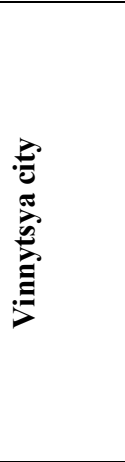 & 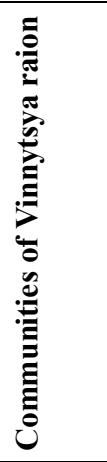 & 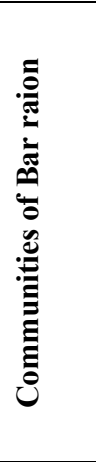 & 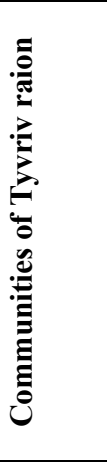 & 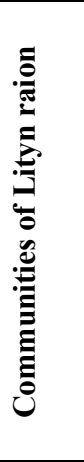 & 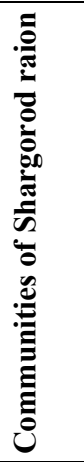 & 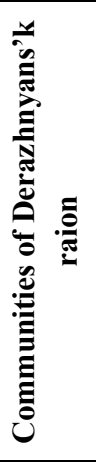 \\
\hline \multicolumn{10}{|l|}{2016} \\
\hline Zhmerynka city & & 1,4 & 4,6 & 1,3 & 0,3 & 0,1 & 0,2 & 0 & 0 \\
\hline $\begin{array}{l}\text { Communities of } \\
\text { Zhmerynka raion }\end{array}$ & 6,6 & & 13,2 & 1,7 & 0,3 & 0,5 & 0,4 & 0,2 & 0,1 \\
\hline Vinnytsya city & 0,2 & - & & 6,9 & 0,3 & 0,6 & 0 & 0 & 0 \\
\hline $\begin{array}{l}\text { Communities of } \\
\text { Vinnytsya raion }\end{array}$ & 0,6 & 0,9 & 28,5 & 0 & 0,5 & 0,2 & 0 & 0,2 & 0 \\
\hline $\begin{array}{c}\text { Communities of Bar } \\
\text { raion } \\
\end{array}$ & 0,7 & 0,3 & 3,7 & 1,9 & 0 & 0 & 0,2 & 0 & 0 \\
\hline $\begin{array}{l}\text { Communities of } \\
\text { Tyvriv raion }\end{array}$ & 0,1 & 0,4 & 6,3 & 2,1 & 0 & 0 & 0 & 0,2 & 0 \\
\hline $\begin{array}{l}\text { Communities of Lityn } \\
\text { raion }\end{array}$ & 0 & 0 & 7,5 & 3,4 & 0,2 & 0 & 0 & 0 & 0,4 \\
\hline $\begin{array}{l}\text { Communities of } \\
\text { Shargorod raion }\end{array}$ & 1,6 & 1,1 & 4,2 & 1,3 & 0,3 & 0 & 0 & 0 & 0 \\
\hline $\begin{array}{c}\text { Communities of } \\
\text { Derazhnyans'k raion }\end{array}$ & 0 & 0 & 0,9 & 0,4 & 0 & 0 & 0,2 & 0 & 0 \\
\hline
\end{tabular}

Assessment of inter-municipal institutional relations. Institutional ties are determined by the territorial agencies of the ministries and other central executive bodies (territorial agencies of central executive bodies TACEB), state and municipal institutions, enterprises, organizations that serve several or all local communities of the territory presented at the level of the local community.

In order to determine the intensity of interaction for this type of ties, the formula, which determines the intensity of any phenomenon was used: in the numerator there is the number of the cases of a special kind, in the denominator is the main set of cases. Thus, the intensity coefficient of inter-municipal institutional relations will be equal to the ratio of the number of TACEB, state and municipal institutions, enterprises, organizations that serve the local community $\boldsymbol{i}$, but located in the local community $\boldsymbol{j}$, to the total number of TACEB, state and municipal institutions, enterprises, organizations under consideration:

$$
K=\frac{v_{i j}}{S}
$$

where

K - intensity coefficient of institutional ties;

$\mathbf{V}_{\mathbf{i j}}$ - the number of TACEB, state and municipal institutions, enterprises, organizations that serve the local community $\mathbf{i}$, but are located in the territory of the local community $\mathbf{j}$;

$\mathbf{S}$ - the total number of TACEB, state and municipal institutions, enterprises, organizations under examination.

This ratio is calculated for each pair of local communities under examination and shows the degree of institutional dependence of local communities on each other.

In order to calculate the total intensity coefficient of institutional ties, we use the formula (4):

$$
\mathrm{K} \cdot=\frac{\sum \mathrm{V}_{\mathrm{ij}}}{\mathrm{S}}
$$

The general intensity coefficient of inter-municipal institutional ties characterizes the intensity degree of ties between all considered local communities together. Being based on the results of the analysis of all types 
of ties, a matrix of inter-municipal ties is built. It reflects the number of existing ties for each pair of local communities. Being based on the data of the matrix, the level of local communities' interaction development is estimated: periodic ties (the coefficient is less than 0.2), regular ties (the coefficient is 0.2-0.5), intensive ties (the coefficient is from 0.5 to 1 ).

In particular, the intensity coefficient of institutional ties between local communities of Zhmerynka raion and neighboring raions and cities of oblast importance is characterized by the following (Table 2), which is facilitated by the inter-raion nature of some TACEB, state and municipal institutions, enterprises and organizations.

Table 2. The intensity coefficient of institutional ties between local communities of Zhmerynka raion and neighboring raions and cities of oblast importance

\begin{tabular}{|c|c|c|c|c|c|c|c|c|c|}
\hline & 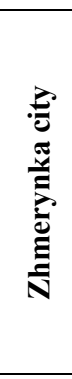 & 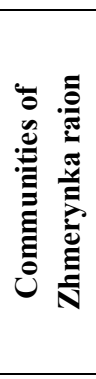 & 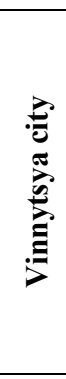 & 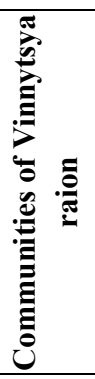 & 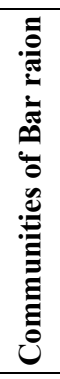 & 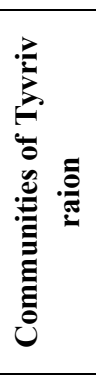 & 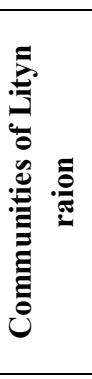 & 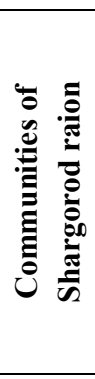 & 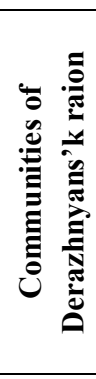 \\
\hline Zhmerynka city & & 0,9 & 0,7 & 0 & 0 & 0 & 0 & 0 & 0 \\
\hline $\begin{array}{l}\text { Communities of } \\
\text { Zhmerynka raion }\end{array}$ & 0,9 & & 0,7 & 0 & 0 & 0 & 0 & 0 & 0 \\
\hline Vinnytsya city & 0,7 & 0 & & 0 & 0 & 0 & 0 & 0 & 0 \\
\hline $\begin{array}{c}\text { Communities of Vinnytsya } \\
\text { raion }\end{array}$ & 0 & 0 & 0,9 & & 0 & 0 & 0 & 0 & 0 \\
\hline Communities of Bar raion & 0,5 & 0 & 0,4 & 0 & & 0 & 0 & 0 & 0 \\
\hline $\begin{array}{c}\text { Communities of Tyvriv } \\
\text { raion }\end{array}$ & 0,3 & 0,1 & 0,3 & 0,1 & 0 & & 0 & 0,1 & 0 \\
\hline $\begin{array}{l}\text { Communities of Lityn } \\
\text { raion }\end{array}$ & 0,4 & 0 & 0,3 & 0 & 0 & 0 & 0 & 0 & 0 \\
\hline $\begin{array}{c}\text { Communities of Shargorod } \\
\text { raion }\end{array}$ & 0,4 & 0 & 0,4 & 0 & 0 & 0 & 0 & 0 & 0 \\
\hline $\begin{array}{c}\text { Communities of } \\
\text { Derazhnyans'k raion }\end{array}$ & 0 & 0 & 0,2 & 0 & 0 & 0 & 0 & 0 & 0 \\
\hline
\end{tabular}

The examination of cooperation agreements of local communities allows to identify the most difficult issues of local importance.

The analysis of the activity of existing intermunicipal organizations allows to determine the most developed types of ties of local communities at this level.

The degree of the development of local communities' interaction can be assessed by: i) interviewing village, town, city mayors, heads of raion councils, ii) an expert survey of heads of executive bodies of local councils. This information allows to determine the preconditions for inter-municipal interaction, to reveal the existing ties between local communities and to reveal the opinion of the representatives of local communities about the priority areas of cooperation. The use of this method allows to diagnose the understanding of the nature of cooperation of local communities as a function of local self-government, to identify the spatial attraction of settlements for common interests and problems.

The questionnaire (offered within this method) consists of two parts. The first part contains a list of issues of local importance of local communities.
Regarding each issue, the respondent is asked to indicate how actively his/her local community participates in inter-municipal interaction.

The second part of the questionnaire includes four open-ended questions on the problematic and promising areas of cooperation between local communities:

- Which specific projects on cooperation of local communities do you participate in?

- Which local communities do you have to cooperate most often with?

- What local communities would it be desirable to cooperate with and in what areas?

- Are there any problems in your local community that you cannot solve independently?

The data processing is carried out for each local community separately, for raion or sub-region as a whole.

At the final, fourth, stage of the offered algorithm the generalization and interconnection of results in an estimation of local communities' ties of all kinds is carried out; the explanation of preconditions for development of strategic directions and the mechanism of inter-municipal cooperation development in a region 
is carried out.

\section{Conclusions}

Therefore, the cooperation of local communities at the regional level should be based on the analysis of existing migration, institutional, etc. ties between the communities. Ignoring the latter can lead to the artificiality of any form of inter-municipal cooperation. However, relevant information that is not included into the relevant government classifiers is lacking to analyze the existing ties. This implies the need to develop an appropriate methodology. The proposed methodology i) can be used in the process of projects on cooperation between local communities' development and ii) disseminated through the existing associations of local governments for further use and improvement.

\section{References}

1. On cooperation of local communities: Law of Ukraine №1508, June 17, 2014 (2014).

2. Register of agreements on cooperation of local communities. URL:

http:/www.minregion.gov.ua/napryamkidiyalnosti/regional-dev/rozvytokmistsevohosamovryaduvannya/reyestr/

3. O.I. Grindey, Intermunicipal cooperation is an innovative form of local development. Scientific works [Petro Mohyla Black Sea State University of the Kyiv-Mohyla Academy]. Series: Public Administration. V. 263, I. 252. 54-58 (2015)

4. P.M. Lyubchenko, Cooperation of local communities: theory and practice. Problems of legality. I. 129. 50-59 (2015).

5. Yu.P. Sharov, Potential and tools of cooperation of capable communities under decentralization. Aspects of public administration. 4. 102-110 (2015).

6. H.V. Prikhodko, Intermunicipal cooperation: procedural and legal aspect. Scientific Bulletin of the Academy of Municipal Administration. S.: Law. I. 1. 149-158 (2011).

7. Yu.S. Rogozyan, Agreement on interregional cooperation: basic principles and project development. Investments: practice and experience. 24. 64-68 (2015).

8. K.O. Zakomorna, Intermunicipal cooperation as a trend of constitutional reform in post-socialist states-members of the European Union. State Building and Local Self-Government. I. 33. 90101 (2017).

9. V.D. Poltavets, Inter-municipal cooperation in France. Experience and lessons. Public administration: theory and practice. 2. 214-218 (2013).

10. A. Gelych, Formation of joint communal enterprises, institutions and organizations as a form of cooperation of local communities. Legal Ukraine. 10. 67-71 (2014).

11. V.V. Mamonova, Organizational pluralism of cooperation in local self-government as a reflection of integration processes in the territory. Public administration: theory and practice. I. 3. 6065 (2013).

12. V.D. Poltavets, Forms of voluntary amalgamation of local self-government bodies as a principle of inter-municipal cooperation. Efficiency of public administration. I. 37. 295-299 (2013).

13. S. Bugil, Strengthening the resource base of municipalities through partnership and cooperation. Bulletin of Odessa National University. Series: Economics. V. 21. I. 9. 116119 (2016).

14. Yu.V. Kozachenko, Cooperation of Local communities within the framework of infrastructural transformation. Investments: practice and experience. 20.67-71 (2017).

15. N.D. Chala, Inter-municipal cooperation in managing economic space: social and financial sections. Scientific Bulletin of the Academy of Municipal Administration. Series: Economics. I. 10. 184-194 (2011).

16. D.G. Bezugliy, Project approach in development management and cooperation of enlarged local communities. Aspects of public administration. 9 . 64-70 (2015).

17. V. Demchyshen, On some aspects of the development of inter-municipal cooperation as an innovative tool in the implementation of State regional policy in Ukraine. Viche. 24. 6-9 (2010).

18. N.A. Kostina, Development of cooperation between local communities under reforming local self-government in Ukraine: dis. Ph.D. Classical private university. Zaporizhzhya. 227 (2017).

19. Making development co-operation more effective: How development partners are promoting effective, country-led partnerships. Part II of the Global Partnership 2019 Progress Report (2019). URL: www.oecd.org/dac/effectiveness/Part-II-ofthe-Global-Partnership-Progress-Report.pdf

20. On associations of local self-government bodies: Law of Ukraine №1275-VI. 16.06.09. (2009).

21. L.L. Rybakovs'kyi, Regional migration analysis. M.: Statistics. 278 (1973). 